\section{PEMIKIRAN MUHAMMAD MANNAN TENTANG PRODUKSI}

\author{
Fita N urotul Faizah \\ UIN Walisongo Semarang, Indonesia
}

\begin{abstract}
A bstract
Purpose-This research explains how production-based economy prosperity thinking of Muhammad Abdul Mannan's perspective.

Methods- This research is a library research that seeks to dissect the work of $M$ uhammad $A$ bdul $M$ annan in Islamic Economic; Theory and Practice with descriptive and explorative qualitative methods based on a soci ologicalhistorical approach and analyzed by deduction.

Findings- The results show that the existence of production is present along with human needs. The goal of production is profit oriented and spiritual oriented. To achieve these are required factors of productions that include: land, labor, capital and organization. M annan stressed that production activities should be based on economic welfare. Welfare indicators according to $M$ annan is in the form of increase revenue caused by the increased production of the utilization of resources to the maximum, good human resources as well as natural resources in the production process hereinafter with objective indicators. Whereas, the second indicator in the form of welfare that is subjective is the activity of production which is based on provisions of the shari' ah

Implications/limitations - this research can make a positive contribution to the continuation of the concept of production as supporting the economic welfare of the community in order to participate in improving the economic State.
\end{abstract}

Keywords Production, Economic Welfare, Muhammad Abdul Mannan Paper type Literature review

\Email korespondensi: fitanurotul.faizah@walisongo.ac.id

\section{To cite this article:}

Fita Nurotul Faizah (2019). Pemikiran Abdul Mannan Tentang Produksi. SERAMBI, 1(2), 55 - 68.

D 0I: https:/ / doi.org/ 10.36407/ serambi.v1i2.71
Received: 05 Aug 2019

Revised: 14 Aug 2019

Accepted: 28 Aug 2019

Online: 31 Aug 2019

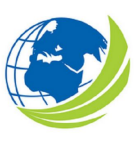

SERAMBI, Vol 1, No 2, Agustus 2019, pp. 55 - 68 eISSN 2685-9904 


\section{Pendahuluan}

Pada dasarnya, pemikiran tentang produksi sudah berkembang sejak manusia mempunyai kebutuhan, baik kebutuhan sandang, pangan, papan dan lain sebagainya (Karim, 2004). Menurut Sadono Sukirno, produksi merupakan proses menciptakan suatu barang maupun jasa yang bisa dimanfaatkan oleh manusia (Sukirno, 2002). Dengan demikian, aktivitas produksi tidak terlepas dari kegiatan keseharian manusia (Nasution, 2007).

Muhammad Abdul Mannan, merupakan seorang tokoh ahli ekonomi yang konsern dalam membahas produksi. Dalam karya master piecenya, Islamic Economic; Theory and Practice, Mannan telah menjelaskan bahwa tujuan produksi selain untuk meningkatkan utilitas suatu produk, juga bertujuan untuk kesejahteraan masyarakat. Di samping itu, sistem produksi dalam Negara Islam haruslah berlandaskan pada aspek objektif maupun subjektif. Aspek objektif merupakan cerminan kesejahteraan dalam bentuk material, sedangkan aspek subjektif teraplikasi pada proses produksi yang mengimplementasikan nila-nilai ekonomi Islam (Mannan, 1989).

Jika menilik pada aspek objektif di atas, maka implikasi kesejahteraan sebuah Negara, pada dasarnya dapat diukur melalui perhitungan GDP (Gross Domestic Product) dan pendapatan perkapita. Di Indonesia sendiri misalnya, menurut BPS (Badan Pusat Statistik) menjelaskan bahwa GDB negara Indonesia dari tahun 2017 sampai dengan tahun 2018 menunjukkan peningkatan yang signifikan dari $5.07 \%$ menjadi 5,17\%. Sedangkan untuk pendapatan perkapita tahun 2018 mencapai Rp 56 juta per tahun, angka ini meningkat daripada tahun 2017 sebesar Rp 51,9 juta per tahun (Badan Pusat Statistik, 2019a). Kondisi ini menginterpretasikan bahwa Indonesia mulai meningkatkan pertumbuhan ekonominya. Tidak hanya itu, kemiskinan yang notabene menjadi masalah terbesar di Indonesia pun mengalami perbaikan. BPS menerangkan bahwa selama periode 2017-2018 tingkat kemiskinan di Indonesia mengalami penurunan, terbukti bahwa di perkotaan angka kemiskinan turun sebanyak 128,2 ribu orang dan di pedesaan turun sebanyak 505 ribu orang. Sayangnya, penurunan garis kemiskinan yang relatif besar tersebut hanya didorong oleh komoditi makanan, sedangkan komoditi non pangan seperti papan, sandang, pendidikan dan kesehatan masih belum berperan aktif (Badan Pusat Statistik, 2019b).

Di sisi lain, dalam aspek subjektif menjelaskan bahwa proses produksi harus berdasarkan prinsip-prinsip ekonomi Islam, sehingga dapat memberikan kemaslahatan kepada stakeholder (Rafsanjani, 2016). Namun, Islam tidak sepenuhnya memberikan kebebasan aktivitas ekonomi seperti pada sistem ekonomi kapitalis, dimana manusia diperbolehkan menumpuk harta bahkan dengan menggunakan cara-cara yang bathil. Dan Islam juga tidak terlalu mengekang dalam sistem ekonomi seperti halnya sistem ekonomi komunisme, sehingga masyarakat kehilangan kebebasan dalam berinovasi. A kan tetapi, Islam telah menetapkan kebijakan terhadap perilaku ekonomi, yakni keadilan dan kewajaran di mana setiap individu memiliki hak yang sama dalam memperoleh kekayaan dengan tanpa mengeksploitasi individu lainnya atau merusak kemashlatan masyarakat (Rahman, 1997). Pendapat ini didukung oleh Rustam Effendi yang menegaskan bahwa tujuan produksi adalah kemaslahatan yang berkeadilan bagi individu (self interest) maupun masyarakat (sosial interest) (Effendi, 2003). Sayangnya, dewasa ini implikasi dari peraturan-peraturan yang sudah ditetapkan sebelumnya hanya berjalan sedikit. Pernyataan ini dipertegas oleh Fahrudin Sukarno, bahwa krisis kemanusiaan pada proses produksi terletak pada mekanisme dan model produksi tanpa pertimbangan moral (moral judgement) (Sukarno, 2010), seperti di Jogjakarta perihal pemusnahan $75 \mathrm{~kg}$ mie basah yang mengandung formalin (Agus Sigit, 2019). Hal ini sangat bertolak belakang dengan prinsip produksi yang dikonsepkan oleh Mannan yang menyebutkan bahwa produksi dapat memberikan manfaat, kesejahteraan dengan tetap mengedepankan produksi yang ramah lingkungan, dan produksi yang berorientasi kesehatan fisik dan psikis manusia. Tidak hanya itu, apotek yang dipercaya khalayak umum dapat membantu dalam proses penyembuhan penyakit, masih banyak 
yang berlaku curang (Arya Wiguna, 2019), seperti peniadaan stok obat yang seharusnya dapat dikonsumsi oleh pasien, produk obat-obatan yang masih ditemukan mengandung bahan pengawet, penjualan obat kadaluarsa, dan lain sebagainya.

Menanggapi masalah di atas, faktor apa yang menyebabkan hal tersebut terjadi? Apakah dikarenakan oleh sistem produksi yang dijalankan, atau karena ada hal lain yang tidak diikutsertakan dalam proses produksi?, selanjutnya bagaimana relevansi pemikiran Mannan terkait konsep kesejahteraan di era modern ini?. Penulisan artikel ini dimaksudkan untuk menjelaskan pemikiran Muhammad Abdul Mannan tentang teori produksi berbasis kesejahteraan masyarakat yang diambil dari buku Islamic E conomic; Theory and Practice.

\section{Landasan Teori}

Produksi

Produksi muncul seiring dengan lahirnya manusia di bumi (Kamma, 2015). Istilah "produksi" menjadi bagian kosakata dalam bahasa Indonesia bersamaan dengan diserapnya istilah "distribusi" dan "konsumsi". Produksi dalam kamus bahasa Inggris-Indonesia mengandung arti "penghasilan" (Shadily, 1996). Konsep produksi dalam terminologi ekonomi, memiliki beberapa perbedaan. Dalam istilah konvensional, produksi didefinisikan sebagai proses mengolah sumber daya menjadi produk/ barang jadi (Hakim, 2012). Lebih jelas, Ace Partadireja mendefiniskan produksi sebagai kegiatan untuk menci ptakan atau menambah utilitas suatu benda (Partadireja, 1992). Sedang menurut Joesron dan Fathorozi produksi merupakan hasil akhir dari pemanfaatan input dalam proses produksi (Setiawan \& Prajanti, 2011). Jadi, menurut sudut pandang ekonomi konvensional, orientasi produksi merupakan pengubahan input menjadi output, sehingga memiliki nilai guna dalam kehidupan. Berbeda dengan ekonomi konvensional, dalam literatur ekonomi Islam, istilah produksi berasal dari bahasa arab "al-intaj" yang secara harfiah berarti "ijadul silatin" (menciptakan atau mengadakan sesuatu) (Sumar'in, 2013). Secara terminologi, produksi berarti aktivitas manusia dalam memanfaatkan sumber-sumber ekonomi yang disediakan oleh sang Kholiq guna menciptakan atau menambah manfaat yang bertujuan untuk memenuhi kebutuhan manusia (Adesy, 2016). Atas dasar terpenuhinya kebutuhan manusia itulah, akhirnya produksi dapat mewujudkan kemaslahatan.

Tujuan Produksi

Secara umum, Profit oriented menjadi dasar sebagai produsen dalam melalukan produksi yang dimulai dengan pemanfaatan faktor produksi sehingga menghasilkan output berupa barang ataupun jasa. Dalam ekonomi Islam, profit oriented bukanlah satu-satunya tujuan utama, melainkan juga diperlukan adanya implementasi prinsip ekonomi syari'ah sebagai pedoman aktifitas produksi guna menciptakan maslahah. Pencapaian maslahah tersebut akan mendorong tercapainya falah sebagai tujuan akhir aktifitas ekonomi sekaligus tujuan hidup manusia. Falah merupakan kebahagiaan hakiki berupa kemuliaan atau pengangkatan kualitas hidup di dunia dan akhirat (Turmudi, 2017). Menurut khalifah Umar bin Khatab, tujuan produksi dalam perspektif fiqh ekonomi meliputi: 1) optimalisasi dalam merealisasikan keuntungan 2) Merealisasikan kecukupan individu dan keluarga, 3) mandiri atau tidak mengandalkan orang lain, 4) Melindungi harta dan mengembangkannya, 5) Mengeksplorasi sumber-sumber ekonomi dan mempersiapkannya untuk dimanfaatkan, 6) mereal isasikan kemandirian ekonomi, 7) T aqarrub kepada Allah SWT (Hakim, 2012).

Prinsip Produksi

Pada prinsipnya aktivitas produksi berkaitan erat dengan prinsip ekonomi syari'ah, dimana seluruh kegiatan produksi harus sejalan dengan tujuan aktivitas ekonomi yang lain, seperti konsumsi maupun distribusi, yaitu mencari falah (Kamma, 2015). Secara umum, prinsip produksi meliputi: 
1. Prinsip tauhid (at-tauhid). Prinsip ini menyebutkan bahwa aktifitas produksi tidak hanya melibatkan hubungan secara horizontal (hablun minannas) melainkan juga hubungan secara vertikal (hablun minallah). Sehingga, aktifitas ini merupakan bagian dari implementasi pertanggungjawaban dan motivasi manusia dalam beribadah kepadaNya.

2. Prinsip kemanusiaan (al-insaniyyah). Implementasi al-insaniyyah adalah bahwa manusia mempunyai hak untuk mencapai kesejahteraannya dengan mengaktualisasikan kemampuan produktif yang mereka miliki.

3. Prinsip keadilan (al-'adl). Perilaku adil akan memberikan kontribusi positif terhadap peningkatan kualitas hidup manusia. Dengan berlaku adil, artinya manusia tidak melakukan dikotomi terhadap manusia lain, sehingga manusia secara umum mendapatkan apresiasi terhadap apa yang mereka kerjakan dan mereka miliki.

4. Prinsip kebajikan (al-maslahah). M aslahah memiliki implikasi terhadap pola hubungan vertikal maupun horizontal. Pada dimensi vertikal, mendeskripsikan kebajikan dan balasan atas pelaksanaan perintah Allah SWT. Sedangkan dimensi horizontal mendeskripsikan kebajikan terhadap sesama manusia serta lingkungan alamnya.

5. Prinsip kebebasan (al-hurriyah) dan tanggung jawab (al-fardh). Manusia secara utuh memiliki kebebasan atas apa yang mereka kerjakan. A kan tetapi, dalam kebebasan tersebut juga menuntut adanya pertanggungjawaban. Dalam kegiatan produksi, manusia diharuskan dapat mengambil manfaat, mengeksplorasi dan mengelola sumber daya ekonomi tanpa diiringi dengan merusak dan bertanggung jawab terhadap pelestariannya. Ini mengidentifikasikan bahwa setiap perbuatan manusia memiliki konsekuensi logis terhadap prinsip moral dan psikologis, yaitu tanggung jawab terhadap diri sendiri, masyarakat dan penciptanya.

Faktor Produksi

Sukirno mendefinisikan faktor produksi sebagai benda-benda yang tersedia di alam atau diciptakan manusia dan dimanfaatkan sebagai bahan input guna menghasilkan barang atau jasa. Sumber daya alam yang dapat dimanfaatkan oleh manusia untuk menambah utilitas barang dan jasa disebut dengan faktor produksi. Elemen faktor produksi, pada dasarnya belum pasti. Ini sebagaimana diungkapkan oleh A.H.M. Sadeq yang menyatakan belum adanya kesepakatan diantara penulis asing terhadap faktor produksi. Sebagian penulis menyebutkan faktor produksi terdiri dari empat elemen, sedang yang lain mengatakan hanya tiga (Sadeq, 1981). Seperti, Yusuf Qardhawi yang merumuskan faktor produksi berupa alam, usaha/ kerja dan manusia (Qardawi, 1997). Menurutnya, produksi merupakan hasil integrasi antara alam, usaha/ kerja dengan manusia. Hal ini sebagaimana firman Allah dalam surat Huud ayat 61.

"D an kepada Tsamud (kami utus) saudara mereka shaleh. Shaleh berkata: "Hai kaumku, sembahlah Allah, sekali-kali tidak ada bagimu Tuhan selain Dia. Dia telah menciptakan kamu dari bumi (tanah) dan menjadikan kamu pemakmurnya, karena itu mohonlah ampunan-Nya, kemudian bertobatlah kepada-Nya, Sesungguhnya Tuhanku A mat dekat (rahmat-N ya) lagi memperkenankan (doa hambaNya)" (Indonesia, 2004)

Faktor produksi secara umum, mencakup:

Faktor alam/ tanah

Faktor alam merupakan faktor dasar dalam produksi yang mencakup bumi dan segala isinya, baik yang ada di atas permukaan bumi maupun kandungan bumi itu sendiri. Urgensi tanah sebagai faktor produksi bukan sebatas luas atau sempitnya lahan, melainkan juga dari segi macam kesuburan dan penggunaan tanah (Muin, 2017). Pemanfaatan alam sebagai sumber daya alam mengindikasikan adanya motivasi terhadap upaya pencapaian kesejahteraan. Rasulullah Saw. sangat memperhatikan pemanfatan tanah mati (ihya al-mawat) sebagai sumberdaya bagi kemakmuran rakyat. Hal tersebut dimaksudkan untuk memberi dorongan kepada seseorang dalam mengembangkan (mengelola) 
tanah. Islam juga membolehkan pemilik tanah menggunakan sumber-sumber alam yang lain sebagai bahan produksi.

Faktor tenaga kerja

Fungsi tenaga kerja adalah sebagai pendayaguna faktor alam/ tanah. Bagi perusahaan, tenaga kerja merupakan asset, sebab keberhasilan produksi terletak pada kinerja tenaga kerja yang dianggap sebagai sumber daya manusia. Dengan demikian, tenaga kerja sangat dibutuhkan dalam proses mentransformasikan input menjadi output, sehingga perusahaan harus memperlakukan tenaga kerja dengan semestinya. Artinya, perusahaan dilarang mengeksploitasi ataupun menganggap rendah tenaga kerja. Begitupun sebaliknya, tenaga kerja yang menduduki faktor produksi penting juga tidak boleh melakukan tindakan sewenang-wenang. Karena pada dasarnya, tenaga kerja memiliki hak yang harus diterima dan kewajiban yang harus diselesaikan.

Faktor modal (capital)

Modal merupakan alat/ bahan yang digunakan untuk membantu proses produksi. Menurut sumbernya, modal dibedakan atas, 1) modal dari alam (semua yang terdapat di alam yang dapat dimiliki dan dapat dimanfaatkan untuk produksi), 2) modal sendiri atau modal pribadi, dan 3) modal pinjaman (modal yang diperoleh dari hasil pinjaman baik dari perorangan, lembaga maupun perbankan).

Faktor $M$ anajemen

Manajemen merupakan ilmu atau seni dalam merencanakan, mengorganisasikan, mengaktualisasi dan mengontrol jalannya perusahaan dalam mencapai tujuan. Manajemen memiliki peran penting dalam aktivitas produksi. Semua faktor produksi tidak akan menghasilkan profit maksimal apabila proses manajerialnya kurang baik. Proses manajerial memerlukan skill/ keahlian berupa skill untuk mengatur dan skill untuk memimpin. Skill untuk mengatur merupakan suatu keterampilan dimana seorang manajer harus mampu melakukan perencanaan, pengaturan, atas aturan ataupun konsep bagi pengembangan perusahaan. Sedangkan, skill untuk memimpin berupa kemampuan untuk menggerakkan agar rencana yang telah dibuat dapat berjalan dan terkendali sehingga tujuan yang tertera dalam rencana betul-betul dapat terealisasikan. Terdapat lima unsur pokok yang harus dimiliki oleh pemimpin, diantaranya 1) pemahaman terhadap konsep, 2) penyampaian konsep, 3) memotivasi, 4) mengarahkan, 5) mengawasi atau mengendalikanjalannya perusahaan.

\section{Metode Penelitian}

Penelitian ini merupakanpenelitian kepustakaan (library research) dengan metode kualitatif deskriptif dan eksploratif yang bertujuan untuk menggambarkan secara mendalam hal-hal yang berkaitan dengan konsep produksi menurut Mannan dalam karya master piecenya Islamic Economic; Theory and Practice. Di samping itu, pendekatan dalam penelitian ini adalah sosiologis-historis yang berguna untuk menerangkan gejala yang berkaitan dengan aspek kegiatan interaksi antara manusia satu dengan manusia lainnya (Rianto, 2004) dan menerangkan semua kegiatan tokoh dan latar belakangnya (Creswell, 2015), meliputi ide seorang tokoh, latar belakang kehidupan serta perjalanan pendidikannya. Untuk menganalisa penelitian ini menggunakan pendekatan deduksi dimana pengambilan kesimpulan berasal dari penemuan umum ke khusus dengan menggunakan penalaran deduktif dan untuk mencapai kesimpulan logis tertentu berdasarkan teori-teori yang relevan dengan tema produksi perspektif Mannan.

\section{Hasil dan Pembahasan}

Pembahasan 
Produksi P erspektif M uhammad A bdul M annan

Definisi Produksi

Mannan menjelaskan bahwa produksi bukanlah proses penciptaan fisik sesuatu yang tidak ada, melainkan usaha bersama untuk menghasilkan/ menambah utilitas barang/ jasa guna kesejahteraan bersama (Mannan, 2009). Utilitas barang/ jasa tersebut berkisar pada produksi hal-hal yang halal, menguntungkan (Haneef, 2010) dan diproses sesuai dengan ketentuan syari'at, baik dari segi zat, proses pengolahan maupun outputnya. Pendapat Mannan tersebut, pada dasarnya merupakan refleksi dari pemikiran ekonom muslim sebelumnya, bahwa pada masa Rasulullah, produksi sudah berlangsung meskipun tidak menyebutkan istilah produksi secara utuh, melainkan substansi yang terkandung dalam setiap aktivitas muamalah yang telah dilakukan masyarakat pada masanya (AIHaritsi, 2014). Seperti yang dikutip oleh Muhammad Nejatullah Siddiqi bahwa pada masanya, Rasulullah SAW telah menghimbau kepada ummatnya untuk melakukan aktivitas produktif seperti perniagaan, pertanian, peternakan, atau kegiatan produktif lainnya. Islam menjunjung tinggi bagi mereka yang melaksanakan aktivitas ekonomi sesuai dengan prinsip syari'ah dan menyetarakannya dengan orang yang melakukan sembahyang atau ahli ibadah (Siddiqi, 1996). Rasulullah bersabda:

"Para pedagang Islam yang jujur dan bersikap benar akan dibangkitkan bersama-sama dengan orang yang mati syahid (pada hari kiamat)".(H.R Ibnu M ajah).

Selanjutnya, pada masa khulafaur rasyidin, istilah produksi masih belum popular, hanya saja secara implisit substansi produksi tercermin dalam beberapa terminologi, seperti: islahul mal (memperbaiki harta), kasab (usaha), imarah (memakmurkan), dan ihtiraf (bekerja) (AI-Haritsi, 2014). Esensi produksi pada masa ini berupa pengoptimalan sumber daya guna menambah manfaat suatu barang atau jasa yang berlandaskan pada aturan-aturan syari'at. Seiring perkembangan waktu, istilah produksi mulai berkembang. Hal ini diungkapkan oleh al-Ghazali (1058-1111M) yang menyebutkan bahwa aktivitas produksi hendaknya didasarkan atas kebutuhan manusia sebagai kewajiban sosial (fard kifayah) (AI-Ghazali, 2011). Lebih jauh, ia mengklasifikasikan produksi berdasarkan tingkatannya yakni industri dasar, aktivitas penyokong dan aktivitas komplementer (Karim, 2004). Pandangan ini kemudian berkembang pada masa kontemporer yang melahirkan beberapa tokoh ekonom muslim seperti Mannan, Baqir as-Sadr, Monzer Kahf, Imam asy-Syatibi, Ibnu Khaldun dan Iain-lain yang konsern terhadap konsep produksi.

Muhammad Baqir as-Sadr yang menganggap bahwa produksi merupakan usaha mengolah sumber daya alam agar memiliki manfaat dan berguna bagi pemenuhan kebutuhan manusia (Effendi, 2003). Sedang produksi menurut Monzer Khaf adalah pemanfaatan kekayaan sumber daya yang tersedia di alam (Khaf, 2000). Disisi lain, Imam Asy-Syatibi (W-1388M) menjelaskan, produksi sebagai penambahan value atas barang atau jasa yang berorientasi pada kemaslahatan. Kemaslahatan menurut Asy-Syatibi berupa terpeliharanya maqasidus syari'ah yang meliputi terpeliharanya agama, jiwa, akal, keturunan dan harta. Sedangkan Ibnu Khaldun (1332-1406M) memandang produksi sebagai usaha manusia dalam memenuhi kebutuhan (Amalia, 2010). Berdasarkan definisi-definisi produksi menurut beberapa tokoh tersebut menunjukkan bahwa produksi perspektif Mannan tidak jauh berbeda meskipun dielaborasi dari berbagai sisi ((P3EI), 2012). Sehingga, pada akhirnya aktivitas produksi mengerucut pada eksistensi manusia sebagai khalifatullah fi al-ardh. Oleh karena itu, secara ringkas produksi berarti proses mengolah atau mengembangkan faktor produksi untuk menghasilkan barang / jasa guna memenuhi need (kebutuhan) baik material maupun non material dengan memperhatikan nilai keadilan dan kebajikan (maslahah) sebagai sarana menuju falah.

1. Tujuan Produksi 
Sama hal nya dengan ekonomi konvensional, Mannan pun menyatakan bahwa tujuan produksi adalah profit oriented. A kan tetapi, profit tersebut tidak akan tercapai secara sempurna manakala Produsen mengesampingkan nilai syari'at (Haneef, 2010) untuk kemaslahatan umat manusia (Rafsanjani, 2016). $\mathrm{Hal}$ ini senada dengan pemikiran Nejatullah Siddiqi dan Monzer Kahf yang sama-sama menitik beratkan syari'at sebagai pijakan utama dalam produksi. Sehingga, tujuan produksi tidak sematamata mencapai kebahagiaan duniawi melainkan juga kebahagiaan akhirat (Aziz, 2008).

2. Faktor Produksi

Secara umum, faktor produksi dirumuskan menjadi tiga hal utama, yaitu alam, modal dan tenaga kerja. Menurut Mannan, faktor produksi lebih dari itu, yakni adanya peran organisasi sebagai unsur keempat dari faktor produksi (Mannan, 1989).

a. Tanah

Menurut Mannan,

"Islam has recognized land as factor of production not exactly in the sense it is used in modern times. In classical writings land, which was regarded as an important factor of production, includes all the natural resources used in the process of production, e. g. the surface of the earth, the fertility of soil, properties of air and water and mineral resources, etc" ( $M$ annan, 1989).

Pernyataan di atas menerangkan bahwa tanah merupakan sumber daya alam meliputi sumber daya alam yang dapat diperbaharui (tidak habis) maupun tidak (habis) yang dapat dimanfaatkan secara maksimal oleh produsen guna mencapai kesejahteraan ekonomi masyarakat dengan berpedoman pada prinsip syari'at. Produsen sebagai pengguna sumber daya al am tidak boleh melakukan kerusakan yang dapat membahayakan keseimbangan alam serta generasi masa depan, seperti melakukan eksploitasi terhadap batu bara dan minyak tanah tanpa melakukan perkiraan dan perencanaan terlebih dahulu (Rozalinda, 2014). Pemanfaatan sumber daya alam harus arif dengan melakukan pemilahan terhadap sumber daya alam yang dapat diperbaharui dan tidak dapat diperbaharui untuk pelestarian dan pengembangannya supaya tidak habis dan terjadi kelangkaan.

b. Tenaga kerja

Fungsi manusia sebagai tenaga kerja adalah pemanfaat dari segala sumber daya alam (Rafsanjani, 2016). Dengan usaha manusia sebagai tenaga kerja baik secara fisik maupun pikiran tersebut, selanjutnya ia mendapatkan imbalan/ upah (Rahman, 1995). Mannan menyebutkan:

"Islam is quite alive to the interest of the employers as well who can also make a positive contribution toward the welfare of the society" (M annan, 1989).

Eksistensi tenaga kerja dalam Islam sangat dijunjung tinggi, sebab dapat memberikan kontribusi positif terhadap peningkatan taraf hidup masyarakat, seperti perusahaan memperoleh output seperti yang direncanakan, sementara tenaga kerja memperoleh imbalan/ intensif dari usaha yang telah mereka curahkan. Oleh karena pentingnya unsur tenaga kerja dalam proses produksi, sehingga tidak hanya sistem ekonomi Islam yang mengakui keberadaan tenaga kerja, melainkan sistem ekonomi kapitalis dan sosialis pun menyatakan hal yang serupa. Seperti yang diungkapkan oleh A dam Smith bahwa setiap kerja merupakan faktor produksi karena dengan tenaga kerja, produsen terbantu dalam memecahkan satu permasalahan pokok produksi, how, dalam permasalahan produksi selain, 
what dan for whom (Poli, 1992). Namun, yang membedakan sistem ekonomi Islam dengan sistem ekonomi lainnya adalah adanya landasan moral dan etika (Rozalinda, 2014) dalam hubungan antara buruh/ tenaga kerja dan majikan seperti, sistem pengupahan, perlakuan, sistem kerja, dan lain sebagainya.

C. Modal

Modal sering didefinisikan sebagai harta yang dapat membantu menghasilkan harta lainnya. Mannan menjelaskan, "capital is producted by the expenditure of labour and the use of natural resources" (Mannan, 1989). Pada prinsipnya, modal bukan merupakan faktor produksi utama. Kedudukan modal adalah sebagai sarana untuk mengadakan tanah dan tenaga kerja. Semua benda yang bernilai selain tanah disebut sebagai modal termasuk benda-benda milik umum.

Modal berkaitan erat dengan bunga. Sementara itu, Islam mengharamkan transaksi yang mengandung bunga. Sebagaimana Mannan mengungkapkan bahwa "the Islamic economic system must be free of interest". Bunga merupakan ziyadah (tambahan) yang diperoleh dari transaksi utang piutang. Sementara ziyadah termasuk dalam kategori riba. Hal ini diperjelas dalam Q.S al-Baqarah: 275 yang menerangkan bahwa "Allah SWT menghalalkan jual beli dan mengharamkan riba". Bagi Islam, bunga merupakan penyakit menular yang mematikan. Sebab, dengan penetapan bunga masyarakat dituntut untuk membayar tambahan wajib dari pokok hutang seberapapun jumlahnya. Dengan begitu, terjadi penindasan dan eksploitasi si kaya terhadap si miskin (A malia, 2010). Sehingga, masyarakat akan mengalami kesulitan dalam mengembangkan usaha dan nantinya akan berimbas pada stagnasi pertumbuhan ekonomi di sebuah negara. Pengharaman bunga pada dasarnya bertujuan untuk melindungi masyarakat dari tindakan kecurangan, sehingga modal dapat terdistribusi tidak hanya kepada mereka kelompok pemangku modal tertinggi, tetapi juga kepada masayarakat secara merata dan adil (Rozalinda, 2014). Sebagaimana firman Allah:

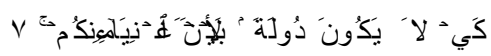

"supaya harta itu tidak beredar di antara orang-orang kaya saja di antara kamu".(Q.S al-Hasyr:7) (Indonesia, 2004).

d. Organisasi

Organisasi adalah wadah kerjasama untuk melaksanakan misi guna mencapai visi yang telah ditetapkan (Sucipto, 2010). Sistem kerja organisasi mengupayakan perpaduan pengolahan antara ketiga faktor produksi, yakni tanah, tenaga kerja dan modal dalam aktivitas produksi (Rahman, 1995). Konsep organisasi dalam Islam berbeda dengan konvensional. Organisasi dalam kacamata konvensional hanya berupaya semaksimal mungkin bagaimana tujuan yang hendak dicapai oleh sebuah perusahaan tercapai. Sementara ekonomi Islam, beranggapan bahwa dalam pencapaian tujuan perusahaan, mutlak berlandaskan pada al-Qur'an dan Hadis sebagai pondasi utama. Dalam al-Qur'an Surat ash-Shaf: 4 dijelaskan bahwa "sesungguhnya Allah SWT menciptakan orang-orang yang berperang di jalan-Nya dalam barisan yang teratur, mereka seakan seperti bangunan yang tersusun kokoh".

Selain itu, Ali bin Abi Thalib r.a. menerangkan, "kebenaran yang tidak terorganisasi dengan rapi, dapat dikalahkan oleh kebatilan yang diorganisasi dengan baik" (Sucipto, 2010). Dengan demikian, pengorganisasian terhadap aktifitas ekonomi merupakan hal yang urgen. Urgensi organisasi Islam menghendaki usaha yang halal, baik zat (bahan baku), cara perolehan, cara penggunaannya, mendasarkan usaha pada kekayaan bukan pinjaman, 
mengutamakan kepentingan sosial, adanya integritas moral, ketepatan dan kejujuran dalam accounting.

Pemikiran M uhammad A bdul M annan tentang Produksi Berbasis K esejahteraan M asyarakat

Kesejahteraan merupakan dambaan setiap manusia (Prayuda, 2017) sehingga manusia akan senantiasa berusaha secara optimal untuk mencapainya (Basrowi, 2014). Kesejahteraan berasal dari akar bahasa sansekerta, yaitu "catera" yang berarti "payung". Catera merupakan sebuatan bagi penyandang kesejahteraan, kemakmuran, terbebas dari kekhawatiran sehingga hidupnya aman dan tentram, baik lahir maupun batin (Fahrudin, 2012). Sedangkan dalam Kamus Besar Bahasa Indonesia, kesejahteraan berasal dari kata "sejahtera" yang berarti "aman, sentosa, makmur dan selamat" (Poerwadarminta, 1999). Menurut Edi dalam Maltuf (Fitri, 2017) menjelaskan langkah menuju kesejahteraan meliputi tiga hal, yakni: 1) terpenuhinya kebutuhan jasmani, rohani serta sosial, 2) tersedianya usaha produktif guna memenuhi tiga kebutuhan pokok (jasmanai, rohani maupun sosial), 3) adanya intervensi lembaga kesejahteraan sosial dalam institusi.

Lebih jauh, dalam konteks kenegaraan, kesejahteraan secara khusus diatur dalam UU No. 11 tahun 2009 yang berisi tentang Kesejahteraan Sosial, menyebutkan bahwa "Kesejahteraan sosial adalah kondisi terpenuhinya kebutuhan material, spiritual, dan sosial warga negara agar dapat hidup layak dan mampu mengembangkan diri, sehingga dapat melaksanakan fungsi sosialnya". Dengan demikian, jelaslah bahwa struktur bangun kesejahteraan adalah terpenuhinya kebutuhan material maupun non material.

Kajian kesejahteraan perspektif ekonomi Islam juga dibahas oleh Muhammad Abdul Mannan. Dalam buku Islamic Economic; Theory and Practice, Mannan menyebutkan bahwa:

"The fundamental principle which is to be kept in view in the process of production is the manifestation of the principle of economic welfare. Even in the capitalistic system there is cry for production of goods and services based on the principle of economic welfare. The uniqueness of the Islamic concept of economic welfare lies in the fact that it cannot ignore the broader considerations of the general welfare which involves in the question of morality, education, religion and many other things. In modern economics, economic welfare is measured in terms of money" (M annan, 1989).

Mannan menerangkan bahwa indikator kesejahteraan meliputi kenaikan jumlah pendapatan yang disebabkan oleh peningkatan jumlah produksi yang didasarkan pada konsep ekonomi Islam (Rozalinda, 2014). Oleh karena pada prinsipnya, tolak ukur keberhasilan sistem ekonomi bersumber dari sejauhmana tingkat keseimbangan antara kebutuhan material dan kebutuhan etika (Gufron, 2015).

Seiring perkembangan zaman, kebutuhan etika menjadi urgen. Apabila kegiatan dalam rangka memenuhi kebutuhan ekonomi tidak mempunyai batas-batas moral yang jelas dan menuju pada materialis, amoralis, dan korupsi, maka akan mengakibatkan goyahnya kestabilan ekonomi masyarakat. Selain itu, masyarakat akan menghadapi persaingan dan permusuhan, hilangnya sikap saling bekerja sama dan kasih sayang, dan akhirnya akan membawa pada penghancuran dan kekacauan pada masyarakat (Rahman, 1995).

Di samping itu, memproduksi barang-barang dagangan (komoditi) yang tercela, diharamkan dalam Islam, karena tidak baik dari segi kesehatan, maupun dari segi moral, seperti minum-minuman beralkohol dan minum-minuman keras. Tujuannya adalah agar manusia lebih selektif dalam berproduksi, sehingga selain untuk kemaslahatan umat masa kini juga akan menjamin kelangsungan umat di masa depan. Dengan demikian, keseimbangan antara moral dan material menjadi penting untuk dijaga (Gufron, 2015). Secara terang-terangan, Islam telah menyebutkan indikator pengukur kesejahteraan masyarakat, seperti dalam al-Qur'an surat an-Nisa': 9,

"dan hendaklah takut kepada Allah orang-orang yang seandainya meninggalkan dibelakang mereka anak-anak yang lemah, yang mereka khawatir terhadap (kesejahteraan) mereka. oleh sebab itu hendaklah mereka bertakwa kepada A llah dan hendaklah mereka mengucapkan Perkataan yang benar".

Ayat di atas menginterprestasikan bahwa kesejahteraan ekonomi merupakan refleksi dari keberhasilan atas hablun minallah (hubungan dengan Allah SWT) dari orang-orang yang jujur dan 
bertaqwa kepada Allah SWT. Selain hablun minallah, faktor hablun min an-nas (hubungan dengan manusia) juga merupakan penentu keberhasilan kesejahteraa ekonomi. Ini terinterpretasi dari adanya perhatian atas sumber daya untuk kelangsungan masa kini dan masa yang akan datang. Sehingga, kehidupan generasi yang akan datang tidak akan terancam kepunahannya (Bahreisy, 1988). Nabi Muhammad SAW menegaskan urgensi pelestarian sumber daya untuk menjamin kelangsungan hidup generasi selanjutnya, yaitu dengan melarang pemberian seluruh harta kepada orang lain yang notabene bukan merupakan ahli waris dan sengaja melalaikan ahli warisnya. Nabi SAW bersabda:

"Dari 'A mir bin Sa'ad, dari ayahnya, Sa'ad, ia adalah salah seorang dari sepuluh orang yang dijamin masuk surga- berkata, "Rasulullah shallallahu 'alaihi wa sallam menjengukku ketika haji Wada', karena sakit keras. A ku pun berkata, "Wahai Rasulullah, sesungguhnya sakitku sangat keras sebagaimana yang engkau lihat.Sedangkan aku mempunyai harta yang cukup banyak dan yang mewarisi hanyalah seorang anak perempuan.Bolehkah saya sedekahkan 2/3 dari harta itu?" Beliau menjawab, "Tidak." Saya bertanya lagi, "Bagaimana kalau separuhnya?"Beliau menjawab, "Tidak."Saya bertanya lagi, "Bagaimana kalau sepertiganya?"Beliau menjawab, "Sepertiga itu banyak (atau cukup besar).Sesungguhnya jika kamu meninggalkan ahli warismu kaya, itu lebih baik daripada kamu meninggalkan mereka dalam keadaan miskin sehingga mereka terpaksa meminta-minta kepada sesama manusia.Sesungguhnya apa yang kamu nafkahkan dengan maksud untuk mencari ridha A lah pasti kamu diberi pahala, termasuk apa yang dimakan oleh istrimu."Aku bertanya, "Wahai Rasulullah, apakah aku akan segera berpisah dengan kawan-kawanku?" Beliau menjawab, "Sesungguhnya engkau belum akan berpisah. Kamu masih akan menambah amal yang kamu niatkan untuk mencari ridha Allah, sehingga akan bertambah derajat dan keluhuranmu. Dan barangkali kamu akan segera meninggal setelah sebagian orang dapat mengambil manfaat darimu, sedangkan yang lain merasa dirugikan olehmu. Y a Allah, mudah-mudahan sahabat-sahabatku dapat melanjutkan hijrah mereka dan janganlah engkau mengembalikan mereka ke tempat mereka semula. Namun, yang kasihan (merugi) adalah Sa' ad bin Khaulah. Rasulullah shallallahu 'alaihi wa sallam sangat menyayangkan ia meninggal di M akkah". (M uttafaqun 'alaih.HR. Bukhari no. 4409 dan M uslim no. 1628).

Dengan demikian, orientasi kesejahteraan selain berhubungan dengan kecukupan material dan terlaksananya mental spiritual dalam produksi juga berimplikasi pada kelangsungan kehidupan generasi yang akan datang (Sodiq, 2016). Ringkasnya, indikator kesejahteraan perspektif Mannan meliputi aspek objektif (diukur berdasarkan kekayaan materi/monetary based) dan subjektif (implementasi prinsip syari'at dalam aktivitas produksi). Oleh karena itu, kajian ekonomi Islam tidak hanya membahas tentang kesejahteraan material saja, tetapi juga non material yang patuh kepada norma-norma Islam (Parmudi, 2017) dan mengajarkan keseimbangan antara kebebasan ekonomi individu dengan keadilan dan kesejahteraan bersama (Fuadi, 2016).

Di samping Mannan, konsep kesejahteraan menurut Chapra adalah adanya korelasi atau hubungan antara prinsip syari'at dengan kemaslahatan. Menurutnya, ekonomi Islam merupakan bagian dari syari'at Islam yang memiliki tujuan utama kebahagiaan dunia dan akhirat (fallah) serta kehidupan yang baik (al-hayah al-thayyibah) (Chapra, 2001).

Pada dasarnya, konsep kesejahteraan menjadi kajian utama di setiap negara, termasuk Indonesia. Indonesia merupakan Negara berkembang yang berusaha memakmurkan rakyatnya sehingga dapat mewujudkan kesejahteraan. Untuk menunjang dita-cita tersebut, rumusan kesejahteraan dituangkan dalam pembukaan UUD 1945, dan kemudian dijabarkan dalam batang tubuhnya, yakni Bab XIV pasal 33 tentang perekonomian nasional dan kesejahteraan sosial (Almizan, 2016). Sehingga, peran pemerintah dalam konteks ini adalah sebagai penyedia pelayanan sosial secara luas kepada warga negaranya. Pengukuran terhadap tinggi rendahnya tingkat kesejahteraan di Indonesia dilakukan oleh BPS. Menurut BPS, Indeks kesejahteraan dapat dihitung melalui besarnya penghasilan keluarga, pengeluaran rumah tangga (baik pangan maupun non pangan), tingkat pendidikan keluarga, kesehatan keluarga, kondisi perumahan dan fasilitas yang dimiliki rumah tangga.

Dewasa ini, menurut BPS tingkat kesejahteraan negara Indonesia mengalami peningkatan yang signifikan.Kondisi ini dinyatakan dengan adanya peningkatan atas GDP (Gross domestic product) dan pendapatan perkapita. Akan tetapi, pada kenyataannya tingkat kemiskinan masih meningkat (seperti yang telah dijelaskan sebelumnya). Menurut hipotesa penulis, kondisi ini terjadi karena 
adanya distribusi yang tidak merata baik distribusi produksi maupun distribusi pendapatan. $\mathrm{Hal}$ ini dapat dibuktikan dengan Indeks Gini Ratio selama 5 tahun terakhir yang masih stagnan diangka 0, 41.

Menelaah kondisi di atas, jika dikomparasikan dengan pemikiran Mannan atas konsep kesejahteraan, maka konsep Mannan atas kesejahteraan masih aktual jika diimplementasikan pada kondisi sebuah negara dewasa ini, hanya saja sebagai penunjang tercapainya kesejahteraan, pemerintah harus ikut andil dalam melakukan intervensi terkait aktivitas perekonomian terutama dalam aspek non material, meliputi:

Pertama, menciptakan kondusifitas moral-moral Islam terhadap keadaan rumah dengan menanamkan kepedulian dan kesetiaan. Kedua, membentuk sistem pendidikan Islami untuk menunjang terwujudnya Negara yang mengedepankan idealisme Islam. Ketiga, menekankan normanorma dan nilai-nilai Islam yang sesuai dengan aturan perundangan dan merumuskan atau memperbaharui aturan atas sanksi bagi pelanggar peraturan (Fuadi, 2016).

Dengan demikian, sebagai umat manusia harus yakin bahwa Allah SWT menciptakan langit, bumi dan segala apa yang ada diantara keduanya untuk kesejahteraan umat manusia. Manusia sebagai khalifatullah fi al ardh dituntut untuk dapat memberdayakan kekayaan tersebut dengan tanpa menimbulkan kerusakan dan ketidakadilan di muka bumi. Meskipun pada nantinya masih akan terjadi kesenjangan ekonomi, karena hal itu merupakan sunnatullah dari wujud keadilan Allah SWT (Almizan, 2016).

\section{Kesimpulan}

Konstruksi pemikiran Mannan tentang produksi berbasis kesejahteraan masyarakat menjelaskan bahwa produksi merupakan penambahan utilitas barang atau jasa yang berlandaskan pada ketentuan syari'at. Berdasarkan hal ini tujuan produksi menurut Mannan tidak hanya berorientasi pada profit oriented, tetapi juga spiritual oriented. Adapun faktor produksi menurut Mannan meliputi: tanah (mencakup semua yang tersedia di alam baik di atas permukaan maupun substansinya), tenaga kerja (adanya pemenuhan hak dan kewajiban sesuai dengan prinsip syari'at atas karyawan kepada majikan maupun sebaliknya), modal (tidak adanya unsur bunga dalam modal) dan organisasi (manajemen yang matang). Di sisi lain, prinsip fundamental yang harus diperhatikan dalam proses produksi adalah kesejahteraan ekonomi. Indikator kesejahteraan ekonomi perspektif Mannan meliputi aspek objektif dan subjektif. Dimana indikator objektif dapat diukur melalui monetary based, sedangkan aspek subjektif dapat diukur berdasarkan implementasi nilai-nilai keisalaman dalam aktivitas produksi, baik pemilihan faktor produksi sebagai bahan input, pengolahan input hingga menjadi output berupa barang maupun jasa.

\section{Referensi}

(P3EI), P. P. dan P. E. I. (2012). Ekonomi Islam. Jakarta: Rajawali Pers.

Adesy, D. pengurus nasional F. \&. (2016). Ekonomi dan Bisnis Islam. Jakarta: PT. RajaGrafindo Persada.

Agus Sigit. (2019). Awas! Mie Basah Berformalin Masuk Jogja. Retrieved August 1, 2019, from krjogja.com website: https:/ / krjogja.com/ web/ news/ read/ 96833/ Awas_Mie_Basah_Berformalin_Masuk_Jogja. Diakses 24Juli 2019

Al-Ghazali. (2011). Ihya' U lumuddin. Jakarta: Republika.

Al-Haritsi, D. J. B. A. (2014). Fikih Ekonomi U mar Bin A I-K hathab. Jakarta: Pustaka AI-Kautsar.

Almizan, A. (2016). Distribusi Pendapatan : Kesejahteraan Menurut Konsep Ekonomi Islam. M aqdis: Jurnal Kajian Ekonomi Islam, 1(1), 63-82. Retrieved from https:/ / journal.febi.uinib.ac.id/ index.php/ maqdis/ article/ view/ 16 (Diakses pada 16Juli 2019)

Amalia, E. (2010). Sejarah Pemikiran Ekonomi Islam. Depok: Gramata Publishing.

Arya Wiguna. (2019). Masih Ditemukan Kecurangan Apotek Mitra BPJS. Retrieved August 1, 2019, 
from radarlombok.co.id website: https:// radarlombok.co.id/ masih-ditemukan-kecuranganapotek-mitra-bpjs.html (Diakses pada 16Juli 2019)

Aziz, A. (2008). Ekonomi Islam; A nalisis M ikro dan M akro. Yogyakarta: Graha IImu.

Badan Pusat Statistik. (2019a). Laju Pertumbuhan Y on Y Produk Domestik Bruto Menurut Lapangan Usaha (Persen), 2017 - 2019. Retrieved August 1, 2019, from bps.go.id website: https:/ / www.bps.go.id/ dynamictable/ 2017/ 05/ 05/ 1255/ -seri-2010-laju-pertumbuhan-y-on-yproduk-domestik-bruto-menurut-lapangan-usaha-persen-2017---2019.html (Diakses pada 16 Juli 2019)

. (2019b). Persentase Penduduk Miskin Menurut Provinsi 2007 - 2019.

Retrieved August 1, 2019, from bps.go.id website:
https:/ / www.bps.go.id/ dynamictable/ 2016/ 08/ 18/ 1219/ persentase-penduduk-miskinmenurut-provinsi-2007---2019.html (Diakses pada 16Juli 2019)

Bahreisy, S. B. dan S. (1988). Terjemah T afsir Singkat Ibnu Katsir Jilid II. Surabaya: Bina IImu.

Basrowi. (2014). Kewirausahaan untuk Perguruan Tinggi. Bogor: Ghalia Indonesia.

Chapra, U. (2001). M asa D epan IImu E konomi (Sebuah T injauan Islam). Jakarta: Gema Insani Press.

Creswell, J. W. (2015). Penelitian Kualitatif dan D esain Reset: M emilih antara Lima Pendekatan. Yogyakarta: Pustaka Pelajar.

Effendi, R. (2003). Produksi dal am Islam. Yogyakarta: Magistra Insania Press.

Fahrudin, A. (2012). Pengantar Kesejahteraan Sosial. Bandung: Refika Aditama.

Fitri, M. (2017). Pengelolaan Zakat Produktif sebagai Instrumen Peningkatan Kesejahteraan Umat. Economica: Jurnal Ekonomi Islam, 8(1), 149. https:/ / doi.org/ 10.21580/ economica.2017.8.1.1830 (Diakses pada 17 Juli 2019)

Fuadi, A. (2016). Negara Kesejahteraan (Welfare State) Dalam Pandangan Islam Dan Kapitalisme. JESI (Jurnal Ekonomi Syariah Indonesia), 5(1), 13. https:/ / doi.org/ 10.21927/ jesi.2015.5(1).13-32 (Diakses pada 2 Juli 2019)

Ghofur, A. (2016). Konsep Riba Dalam Al-Qur'an. Economica: Jurnal Ekonomi Islam, 7(1), 1. https:/ / doi.org/ 10.21580/ economica.2016.7.1.1030(Diakses pada 2 Juli 2019)

Gufron, M. I. (2015). Peningkatan Produksi dalam Sistem Ekonomi Islam sebagai Upaya Pemberdayaan Ekonomi Umat. Dinar Jurnal Ekonomi Dan Keuangan Islam, 2(1). Retrieved from http:/ / journal.trunojoyo.ac.id/ dinar/ article/ view/ 2690(Diakses pada 2 Juli 2019)

Hakim, L. (2012). Prinsip-Prinsip Ekonomi Islam. Surakarta: Penerbit Erlangga.

Haneef, M. I. (2010). Pemikiran Ekonomi I slam K ontemporer. Jakarta: Rajawali pers.

Indonesia, D. agama R. (2004). al-Q ur'an dan Terjemahannya. Bandung: Diponegoro.

Kamma, H. (2015). Urgensi Teori Produksi Dan Perilaku Produsen Dalam Perspektif Islam.M U AM ALAH, $\quad 5(1), \quad 59-70 . \quad$ Retrieved from http:/ / ejournal.iainpalopo.ac.id/ index.php/ muamalah/ article/ view/671(Diakses pada 2 Juli 2019)

Karim, A. (2004). Sejarah Pemikiran E konomi Islam. Jakarta: PT Raja Grafindo Persada.

Khaf, M. (2000). Ekonomi Islam Telaah A nalitik terhadap Fungsi Ekonomi Islam. Yogyakarta: Aditya.

Mannan, M. A. (1989). Islamic Economics; Theory and Practice. Delhi: Idarahl Adabiyati Delli.

(2009). Frontiers Of I slamic Economics. Del hi: Idarah-I adabiyat-I Delli.

Muin, M. (2017). Pengaruh Faktor Produksi Terhadap Hasil Produksi Merica Di Desa Era Baru Kecamatan Tellulimpoe Kabupaten Sinjai. Economix, 5(1). Retrieved from https:/ / ojs.unm.ac.id/ economix/ article/ view/ 5374(Diakses pada 16Juli 2019)

Nasution, M. E. (2007). Pengenal an Eksklusif Ekonomi I slam. Jakarta: Kencana Prenada M edia Group.

Parmudi, M. (2017). DInamika Ekonomi Islam Di Indonesia; Telaah Sosio-Historis Teologis Terhadap 
Fita Nurotul Faizah. Pemikiran Muhammad Abdul Mannan Tentang Produksi...

$\begin{array}{lllll}\text { Bank } \quad \text { Muamalat Indonesia. } & \text { At-Taqaddum, } & \text { 8(1), } & 47 .\end{array}$ https:/ / doi.org/ 10.21580/ at.v8i1.1164(Diakses pada 16Juli 2019)

Partadireja, A. (1992). Pengantar Ekonomika. Yogyakarta: BPFE.

Poerwadarminta, W. J. S. (1999). Kamus U mum Bahasa Indonesia. Jakarta: Balai Pustaka.

Poli, C. (1992). Pengantar IImu Ekonomi. Jakarta: CV. Gramedia Utama.

Prayuda, W. R. (2017). KEadilan Ekonomi Dalam Prespektif Hukum Islam. Al-M ustashfa: Jurnal Penelitian Hukum E konomi Syariah, 2(1), 42. https:/ / doi.org/ 10.24235/ jm.v2i1.1603(Diakses pada 2 Juli 2019)

Qardawi, Y. (1997). N orma dan Etika Ekonomi Islam. Jakarta: Gema Insani Pers.

Rafsanjani, H. (2016). Jurnal Masharif al-Syariah: Jurnal Ekonomi dan Perbankan Syariah. In Jurnal Masharif al-Syariah: Jurnal Ekonomi dan Perbankan Syariah (Vol. 1). Retrieved from http:/ / journal.um-surabaya.ac.id/ index.php/ Mas/ article/ view/ 763(Diakses pada 2 Juli 2019)

Rahim, A. (2015). Konsep Bunga Dan Prinsip Ekonomi Islam Dalam Perbankan Syariah. In H U M A N FALAH: Jurnal Ekonomi dan Bisnis Islam (Vol. 2). Retrieved from http:/ / jurnal.uinsu.ac.id/ index.php/ humanfalah/ article/ view/ 184(Diakses pada 2 Juli 2019)

Rahman, A. (1995). D oktrin E konomi Islam. Yogyakarta: PT. Simpul Rekacitra. . (1997). M uhammad Sebagai Seorang P edagang. Jakarta: Yayasan Swarna Bhumy.

Rianto, A. (2004). M etodologi Penelitian Sosial dan Hukum. Jakarta: Granit.

Rozalinda. (2014). E konomi Islam; T eori dan A plikasinya pada A ktivitas Ekonomi. Jakarta: Rajawalipers.

Sadeq, A. H. M. (1981). Islamic E conomic. Lahore: Dar at-Taarut.

Setiawan, A. B., \& Prajanti, S. D. W. (2011). Analisis Efisiensi Penggunaan Faktor-Faktor Produksi Usaha Tani Jagung Di Kabupaten Grobogan Tahun 2008. JEJAK: Jurnal Ekonomi D an Kebijakan, 4(1). https:/ / doi.org/ 10.15294/ JEJAK.V4I 1.4642(Diakses pada 2 Juli 2019)

Shadily, J. M. E. dan H. (1996). Kamus Inggris Indonesia. Jakarta: PT. Gramedia.

Siddiqi, M. N. (1996). Kegiatan Ekonomi dalam Islam. Jakarta: Sinar Grafika Offset.

Sodiq, A. (2016). Konsep Kesejahteraan Dalam Islam. Equilibrium, 3(2), 380-405. https:/ / doi.org/ http:/ / dx.doi.org/ 110.21043/ equilibrium.v3i2.1268(Diakses pada 2 Juli 2019)

Sucipto, A. (2010). Studi Kelayakan Bisnis. Malang: Aditya Media.

Sukarno, F. (2010). Etika Produksi Perspektif Ekonomi Islam. Ekonomi Islam A I-Infaq, V ol. 1, N 0.

Sukirno, S. (2002). Pengantar T eori M ikro E konomi . Jakarta: RajaGrafindo Persada.

Sumar'in. (2013). Ekonomi Islam. Yogyakarta: Graha IImu.

Turmudi, M. (2017). Produksi dalam Perspektif Ekonomi Islam. Islamadina: Jurnal Pemikiran Islam, 0(0), 37-56. https:/ / doi.org/ 10.30595/ islamadina.v0i0.1528(Diakses pada 24 Juli 2019)

Yuliadi, I. (2009). E konomi Islam Sebuah Pengantar. Yogyakarta: LPPI.

\section{Profil Penulis}

Fita N urotul Faizah, Kelahiran Grobogan 03 Mei 1994. Penulis merupakan Calon Dosen prodi Ekonomi Islam di UIN Walisongo Semarang yang memulai karir pada tahun 2019. Sebelumnya, Penulis mengembangkan karirnya di IAIN Pekalongan dengan pengalaman mengajar Filsafat Ekonomi Islam dan Pengantar Ekonomi Islam dan SMK Ma'arif NU 01 Semarang sebagai guru Akuntansi Syari'ah jurusan Perbankan Syari'ah. 
This page intention to blank......... 